\title{
直方体粗度群の床面バルクスカラー係数に関する風洞模型実験 WIND TUNNEL EXPERIMENT ON BULK SCALAR COEFFICIENT OF URBAN-LIKE ROUGHNESS
}

\author{
萩島 理*, 谷本 潤**, 未永 啓***, 池谷直 樹 ${ }^{* * * *}$ \\ 前田一行****, 成田健一 $* * * * *$ \\ Aya HAGISHIMA, Jun TANIMOTO, Satoru SUENAGA, \\ Naoki IKEGAYA, Kazuyuki MAEDA and Ken-ichi NARITA
}

\begin{abstract}
The authors investigated bulk scalar coefficient $\left(C_{\mathrm{E}}\right)$ of the street in the 3-D canopy with various conditions of arrangement, plan area density $\left(\lambda_{p}\right)$, frontal area index $\left(\lambda_{f}\right)$, and variability of model height in a wind tunnel using salinity method. The results can be summarized as follows.

1) The relationships between $C_{\mathrm{E}}$ and if of both staggered and normal arrayed canopy with uniform height shows different tendency. The $C_{\mathrm{E}}$ of 3-D canopy of staggered and normal pattern have similar value under the sparse $\left(\lambda_{f}\right)$ and dense conditions, in contrast, $C_{\mathrm{E}}$ of staggered canopy is higher than that of normal canopy under the condition of $\lambda_{f}=17.4 \%$.

2) $C_{\mathrm{E}}$ of uniform canopy is larger than that of canopy with height variation under the condition of $\lambda_{f}<17.4 \%$. In contrast, $C_{\mathrm{E}}$ of uniform canopy is smaller than that of canopy with height variation under the condition of $\lambda_{f}=30.9 \%$. Such a tendency is opposite to the result of drag force coefficient.
\end{abstract}

Keywords : mass transfer phenomena between urban surface and atmosphere, salinity method, wind tunnel experiment 都市表面一大気間の物質輸送現象、塩分法、風洞実験

\section{1. 緒言}

近年、行政施策の目標としてヒートアイランド現象緩和が打ち出 され、都市気候モデル 1) 2) の計算結果が行政や設計者の意志決定の 場面に引用される機会は非常に多くなってきている。しかし、様々 な物理メカニズムを記述したサブモデルから構成される都市気候モ デルの精度に関しては、まだ観測データとの比較検証 ${ }^{3)} の$ 積み重ね が必要である。とりわけ、都市表面の大気加熱量の多䓖を決定づけ る都市表面と大気間の熱や水蒸気などのスカラー輸送過程のモデリ ングは重要なポイントであるが、現時点では多くの課題が残されて いる。

例えば、建築環境工学の分野ではこれまで建物表面の対流熱伝達 率と近傍風速または上空風速との関係に関して屋外観測に基づく多

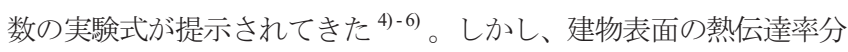
布は周辺建物との間に形成される気流場の 3 次元的分布の影響を強 く受けるため、熱伝達率一風速の実験式は研究者により様々で統一 的な予測手法は確立してしない7)。

一方、大気境界層の底部に位置寸る都市表面を流体力学的な「粗 面」と捉えるならば、都市表面一大気のスカラ一輸送機構は建築工
学分野のみならず伝熱工学、流体力学、都市気候学など幅広い分野 に関連する研究課題である。

例えば都市気候の分野では、Kanda et al. (2007) ${ }^{8)}$ が屋外における 様々な粗度サイズの大気境界層内の熱及び運動量フラックスの観測 に基づき、熱粗度と運動量粗度の比に関するパラメータ $\mathrm{KB}^{-1}$ と粗度 レイノルズ数の関係を提示している。また中立条件の風洞内におい て、ナフタレン昇華法により 2 次元キャノピーのバルク係数を測定 した Barlow et al. (2004) ${ }^{9)}$ 、濾紙蒸発法により 2 次元キャノピーや3 次元キャノピーのバルク係数を測定した Narita $(2007)^{10)}$ によって、 都市形状とスカラー輸送効率の関連について議論が進められており、 単層 ${ }^{11)}{ }^{12)}$ や多層 ${ }^{13)}{ }^{14)}$ の都市キャノピーモデルへの適用を想定した スカラー輸送モデル ${ }^{15)}$ も提案されている。

一方、伝熱工学分野の関連研究としてはナフタレン昇華法に基づ き 2 次元キャビティの物質伝達率分布を測定した Chyu and Goldstein $(1986)^{16)}$ や、立方体粗度群の対流熱伝達率分布を測定した Aliaga et al. (1994) ${ }^{17)}$ などが挙げられる。

このような状況に対し本研究では、風洞模型実験により 3 次元キ ヤノピーの幾何形状の影響が床面のバルクスカラー係数（以下、バ

\footnotetext{
* 九州大学大学院総合理工学研究院 准授 - 博士 (工学)

Assoc. Prof., Interdisciplinary Graduate School of Engineering Sciences, Kyushu Univ., Dr. Eng.

** 九州大学大学院総合理工学研究院 教授. 工博

*** TOTO (株) 修士 (工学)

Prof., Interdisciplinary Graduate School of Engineering Sciences, Kyushu Univ., Dr. Eng. TOTO Ltd., M. Eng.

**** 九州大学大学院総合理工学府 修士課程学生

***** 日本工業大学工学部建築学科 教授. 工博

Master's Student, Interdisciplinary Graduate School of Engineering Sciences, Kyushu Univ. Prof., Department of Engineering, Nippon Institute of Technology, Dr. Eng.
} 
ルク係数）に及ぼす影響を明らかにすることを目標とする。バルク 係数の測定にあたっては、成田らの開発した塩分法 ${ }^{18) ~ 20)}$ を用いる。

成田ら $(1986)^{20)}$ は様々な建蔽率、高さ分布の直方体粗度群の床面 伝達率を塩分法により測定し、粗度群の高さのバラツキ (標準偏差) の増加に伴い床面バルク係数が増加するという結果を得ている。一 方で、ナフタレン昇華法により建蔽率 $25 \%$ の均一高さ粗度群と不均 一高さ粗度群のバルク係数を測定した Pascheke1 et al. (2008) ${ }^{21)}$ によ ると、平均粗度高さが等しい場合、不均一高さ粗度群の方が均一高 さ粗度群より境界層外の流速を reference とするバルク係数は小さく なる、という結果が報告されている。

この $2 つ の$ 実験結果は、粗度の建蔽率や模型形状の違い、測定部 の風上側の模型配列状況などが異なっているため、並べて単純比較 することはできない。しかしいずれにせよ、粗度の高さのバラツキ がバルク係数に与える影響については、現時点で統一的な見解は得 られていない。これは、都市の幾何形状の制御により都市の熱環境 を向上させよう、という近年流行の「風の道」の議論にも影響を与 える可能性のある興味深いテーマである。

そこで本研究では、都市の幾何形状の中でも、とりわけ粗度高さ の不均一性の影響について系統的な議論ができるように、様々な平 面配列および建蔽率の模型配列条件でバルク係数の実験を行う。な お、運動量輸送とスカラー輸送の相似性と相違点についての考察を 行うために、床面抗力係数（すなわち、バルク運動量輸送係数）に ついての萩島ら (2007) ${ }^{22)}$ の風洞実験と同じ模型配列としている。

\section{2. 実験概要}

\section{1 塩分法の測定原理及び測定方法}

塩分法とは、塩水を満たした水槽を風洞の測定部に配置し、気流 下に一定時間静置した前後の塩分濃度の測定值から蒸発量及び物質 伝達率やバルク係数を推定する方法である ${ }^{18) ~ 20)}$ 。本手法は鉛直面の 測定が出来ないという制約はあるが、塩水を満たす水槽のサイズを 大きくしてその中に複数の模型群を並べることで、不均一形状のバ ルクの床面伝達率を推定することが可能であり、同じ水蒸気蒸発を 利用した濾紙蒸発法には無い利点がある。

本研究での実際の測定手順は以下の通りである。まずあらかじめ 作成した塩水を測定部水槽に満たし、残りの塩水を採水し塩分濃度 $S_{\mathrm{B}}$ を測定する。次いで、測定部を一定気流条件下に $\Delta t$ 時間曝露した 後、再び水槽から塩水を採水し塩分濃度 $S_{\mathrm{A}}$ を測定する。これにより (1)式から曝露時間中の蒸発量 $E$ を得る。

$$
E=\frac{\rho_{\text {water }} \cdot V}{\Delta t \cdot A}\left(1-\frac{S_{B}}{S_{A}} \frac{1-S_{A}}{1-S_{B}}\right)
$$

$A$ : 蒸発面面積 $\left[\mathrm{m}^{2}\right], S_{\mathrm{A}}$ : 曝露後塩水濃度 $[\mathrm{psu}], S_{\mathrm{B}}$ : 曝露前 塩水濃度 $[\mathrm{psu}], E$ : 蒸発量 $\left[\mathrm{kg} /\left(\mathrm{m}^{2} \mathrm{~s}\right)\right], \quad V:$ 塩水体積 $\left[\mathrm{m}^{3}\right]$, $\rho_{\text {water }}:$ 水の密度 $\left[\mathrm{kg} / \mathrm{m}^{3}\right], \Delta t:$ 曝露時間 $[\mathrm{s}]$

なお本研究では、曝露時間は 2 時間とし曝露時間中には風洞内の 露点温度、空気温度及び参照風速と水表面温度を連続測定している。 また塩分濃度に関しては、 4 本のサンプル瓶に採水した塩水を各々 5 回連続測定し、全 20 個のデータの平均值を用いている。得られた蒸 発量 $E$ から(2)式により床面バルク係数 $C_{\mathrm{E}}$ が得られる。

$$
C_{E}=\frac{E}{\rho_{\text {air }} U_{\text {ref }}\left(X_{\text {surf }}-X_{\text {air }}\right)}
$$

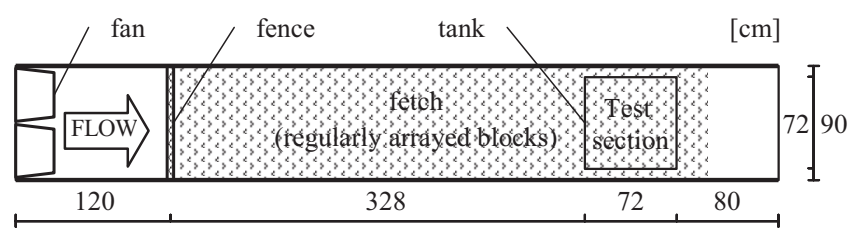

(a) 平面図

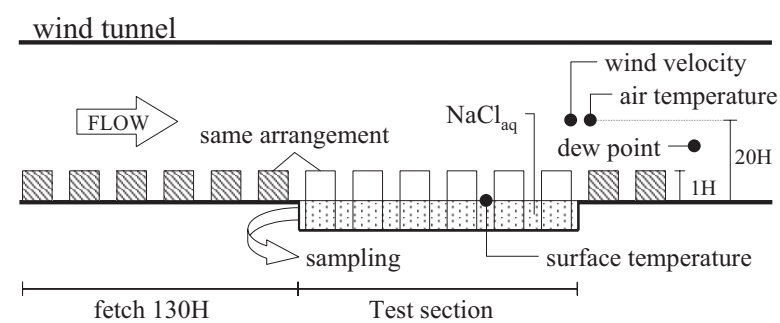

(b) 塩分法による測定箇所付近の模式図 図 1 実験状況の模式図

表 1 測定項目及び測定機器

\begin{tabular}{c|c}
\hline 測定項目 & 測定機器 \\
\hline 塩水濃度 & サリノメーター \\
\hline $\begin{array}{c}\text { 空気温度 }(\mathrm{z}=20 \mathrm{H}), \\
\text { 水表面温度 }\end{array}$ & サーミスタ温度計（テクノセブン, DS101） \\
\hline 露点温度 $(\mathrm{z}=13 \mathrm{H})$ & 鏡面冷却式湿度計（SHINYEI, Dew Star S-1） \\
\hline 参照風速 $(\mathrm{z}=20 \mathrm{H})$ & ピトー管, 精密微差圧計(柴田 ISP-3-20DS) \\
\hline 注) 温度及び流速はデータロガー（NEC 三栄, DC3100）により 30 秒間 \\
隔で計測している。
\end{tabular}

$C_{\mathrm{E}}$ : 床面バルク係数[-], $U_{\mathrm{ref}}$ : 参照風速 $[\mathrm{m} / \mathrm{s}], X_{\mathrm{air}}$ : 空気絶対 湿度 $\left[\mathrm{kg} / \mathrm{kg}^{\prime}\right], X_{\text {surf }}$ : 水面近傍の空気絶対湿度 $\left[\mathrm{kg} / \mathrm{kg}^{\prime}\right], \rho_{\text {air }}$ : 空気密度 $\left[\mathrm{kg} / \mathrm{m}^{3}\right]$

なお、水面近傍空気の絶対湿度は水表面温度の飽和絶対湿度から 推定している。以上の実験を一つの模型配列に対し 3 回行い、3 回 のバルク係数の平均值を解析に用いる。

\section{2 風洞装置及び塩分法の測定部の概要}

本研究では全長約 $6 \mathrm{~m}$ の自作の開放型風洞を用いた。測定洞の寸 法は長さ $4.8 \mathrm{~m}$ 、高さ $0.9 \mathrm{~m}$ 、幅 $0.9 \mathrm{~m}$ で、風洞断面内の気流分布を一 様にするため上流部には 1 枚の金網を設置している。この風洞装置 は温湿度を制御できる室内に設置されている。

風洞の平面図及び床面バルク係数の測定箇所模式図を図 1 に示寸。 金網から約 $3 \mathrm{~m}$ 風下の風洞床に設けた開口部に塩水を満たしたステ ンレス製水槽（72 cm 四方）を設置している。なお、塩水表面は周辺 の風洞床面と同じ高さになるように、注水の際には十分に留意して いる。また、金網から床面バルク係数を測定する水槽前縁までの約 $3 \mathrm{~m}(120 H)$ の領域を水槽部分と同じ模型配列とする事で、粗度の 幾何形状以外の因子がバルク係数の測定に及ぼす影響を極力小さく している。

測定項目及び測定機器を表 1 に示寸。塩水の濃度測定にはサリノ メーターを用いている。この測器は塩性サンプルの導電率比の測定 值から濃度を推定するもので、測定精度を保つため標準海水サンプ ルにより 24 時間毎に較正を行っている。また、水槽風下端の上空 
$500 \mathrm{~mm}$ (基準模型高さ $25 \mathrm{~mm}$ の 20 倍、以下 $20 \mathrm{H}$ とする)において、L 型ピト一管により参照風速を測定している。すべての実験での条件 を揃えるため、参照風速は約 $2 \mathrm{~m} / \mathrm{s}$ （ファンの回転数 $1550 \mathrm{rpm}$ ）一定 としている。

\section{3 模型配列条件}

一辺が $25 \mathrm{~mm}(1 \mathrm{H})$ の立方体模型と $25 \mathrm{~mm}$ 四方で高さが $12.5 \mathrm{~mm}$ の 直方体模型を組み合わせ、規則的に配列する事で粗度群を作成して いる。模型配列の条件を表 2 に、不均一高さ粗度群の模型配列の模 式図を図 2 にそれぞれ示す。平面配置、模型の平均高さ、高さ分布 の異なる 9 ケースについて建蔽率を 3 段階 $\left(\lambda_{p}=7.7,17.4,30.9 \%\right)$ に 変化させ、全 27 条件について床面バルク係数のデータを取得してい る。加えて、滑面のデータとして模型を一切設置しない状態 (水面) での測定を行っている。

各実験ケースの名前は、低層部分の模型配列を大文字、高層部分 の模型配列を小文字でそれぞれ、N・n (整形, Normal array)、 $\mathrm{S} \cdot \mathrm{s}$ (千鳥, Staggered array) と標記し、数值は平均模型高さを意味して いる。最も密な配列における風洞断面に対する模型の立面積は $2.8 \%$

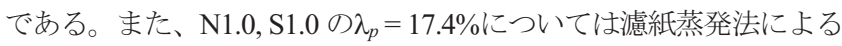
バルク係数の床面内分布の測定を行っている。

以上の模型配列条件、測定対象エリア面積及びフェッチ長さは、 直方体粗度群の床面抗力係数を測定した萩島ら(2007) ${ }^{22)}$ の幾何形 状と全く同一である。

\section{4 濾紙蒸発法による面内分布の測定}

立方体の整形配列 $\mathrm{N} 1.0$ および千鳥配列 $\mathrm{S} 1.0$ の $\lambda_{p}=17.4 \%$ にいて は、塩分法に加え濾紙蒸発法 ${ }^{23)}$ により床面バルク係数の面内分布の 測定を行った。濾紙蒸発法とは水で濡らした濾紙を測定対象面に添 付し一定気流下に静置した場合の前後の重量変化から蒸発量および 物質移動速度を推定する手法である。

バルク係数の測定部位は、塩分法において設置していた水槽の中 央付近の単位街区を 3 分割している。測定部位は、図 3 に示寸通り、 模型後方の gap、スパン方向模型間の street、残り部分 intersection と 名付けている。なお、配列 N1.0 と S1.0 で gap、street、intersection の面積はそれぞれ等しい。

図 3 に示した測定対象エリアは塩分法の水槽に比べて小さいため、 水蒸気濃度境界層の発達状況が塩分法と濾紙蒸発法では同じになら ない。そこで、濾紙試験体の周囲床面に水槽とほぼ同じサイズの濡 らした濾紙（主流方向 $72 \mathrm{~cm} \times$ スパン方向 $90 \mathrm{~cm}$ ）を貼り付けること で、スカラーソース (蒸発面) の大きさを塩分法と同一にしている。 濾紙試験体は底面および小口面をプラスチックフィルムで覆うこと で蒸発以外の要因、例えば周辺濾紙との間の水分移動、による重量 変化が生じるのを防止している。測定は 1 箇所につき $4 \sim 5$ 回行い、 その平均值を解析に用いる。風速条件は塩分法と同じ約 $2 \mathrm{~m} / \mathrm{s} （ フ ァ$ ンの回転数 1550rpm）である。

\section{5 風洞内縮小模型と実在都市との相似}

本実験条件における $R e$ 数（模型寸法と境界層上空流速を代表長 さ、代表速度として定義）は約 $3300 、$ 粗度 $R e$ 数（摩擦速度 $u^{*}$ と粗 度長 $z_{0}$ を代表速度、代表長さとして定義) は約 60 である。Snyder and
表 2 模型配列条件

\begin{tabular}{|c|c|c|c|c|}
\hline Case & $\begin{array}{l}\text { 平面 } \\
\text { 配置 }\end{array}$ & $\begin{array}{c}\text { 模型高さ } \\
H_{a v}\end{array}$ & $\sigma / H_{a v}$ & 備考 \\
\hline $\mathrm{N} 1.0$ & 整形 & $1 \mathrm{H}$ & 0 & $1 \mathrm{H} \times 1 \mathrm{H} \times 1 \mathrm{H}$ の \\
\hline S1.0 & 千鳥 & $1 \mathrm{H}$ & 0 & 立方体模型 \\
\hline $\mathrm{N} 1.5$ & 整形 & $1.5 \mathrm{H}$ & 0 & $1 \mathrm{H} \times 1 \mathrm{H} \times 1.5 \mathrm{H}$ の \\
\hline S1.5 & 千鳥 & $1.5 \mathrm{H}$ & 0 & 直方体模型 \\
\hline N1.5-n & 慗形 & \multirow{4}{*}{$1.5 \mathrm{H}$} & 0.58 & \multirow{4}{*}{$\begin{array}{l}\text { 高さ } 1 \mathrm{H} \text { の立方体模型と } \\
\text { 高さ } 3 \mathrm{H}(1 \mathrm{H} \times 1 \mathrm{H} \times 3 \mathrm{H}) \text { の } \\
\text { 模型を } 3: 1 \text { の割合で配置 }\end{array}$} \\
\hline N1.5-s & \multirow{3}{*}{ 千鳥 } & & 0.58 & \\
\hline S1.5-n & & & 0.58 & \\
\hline S1.5-s & & & 0.58 & \\
\hline N1.5-s* & 整形 & $1.5 \mathrm{H}$ & 0.33 & $\begin{array}{l}\text { 高さ } 1 \mathrm{H} \text { の立方体模型と } \\
\text { 高さ } 2 \mathrm{H}(1 \mathrm{H} \times 1 \mathrm{H} \times 2 \mathrm{H}) \text { の } \\
\text { 模型を } 1: 1 \text { の割合で配置 }\end{array}$ \\
\hline
\end{tabular}

注1) 各ケースとも建蔽率 3 条件 $\left(\lambda_{\mathrm{p}}=7.7,17.4,30.9 \%\right)$ について測定

注2) $H_{a v}$ : 平均模型高さ, $\sigma$ : 模型型高さの標準偏差, $\mathrm{H}=25 \mathrm{~mm}$

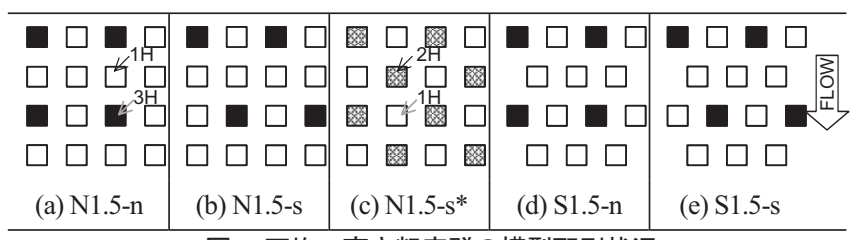

図 2 不均一高さ粗度群の模型配列状況

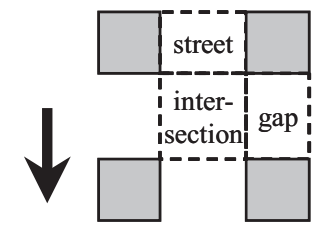

(a) 整形配列 N1.0

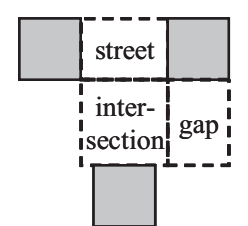

(b) 千鳥配列 S1.0

図 3 濾紙蒸発法の測定箇所
Castro (2002) ${ }^{24)}$ によると、粘性の影響が無視できる十分に発達した 粗面境界層が成立する条件は粗度 $R e$ 数が $O(1)$ を超えていること であるから、粗度周辺の気流場については都市を模擬するのに適切 な条件を満たしていると言える。また、測定部の風上側に測定部と 同じ模型配列が $120 H$ 続いている状況から、速度境界層はある程度 発達していると考えられる。

一方、スカラー輸送については縮小模型と都市における実現象の 間の相似を厳密に議論するのは困難である。一般には、風洞内測定 部の水蒸気濃度およびスカラーソースの分布状況は、模擬しようと する都市域のスカラー境界層およびスカラーソースの分布と類似し ていることが必要とされる。例えば、Barlow et al. (2004) ${ }^{9)}$ や Narita $(2007)^{10)}$ は、隣接する壁面にスカラソースが存在するか否かで模型 壁面や床面のバルク係数が大きく異なることをしている。また、2 次元キャビティの全面にナフタレンを塗布して Chyu and Goldstein $(1986)^{16)}$ の伝達率分布と、模型サイズの 6 分の 1 のサイズの濾紙を 使った Narita $(2007)^{10)}$ による伝達率分布も異なる特性を示している 7)

実際の市街地における温度場を観測した Offerle et al. (2007) ${ }^{25}$ や 萩島ら $\left.(2008)^{26}\right)$ によれば、都市キャノピーの内部は放射不均一によ る表面温度分布により加熱面と冷却面が混在し、なおかつその分布 状況は太陽位置の変化により時々刻々変化している。このような複 雑なスカラーソースの偏在状況を風洞内粗度群に対し再現すること は極めて困難である上に、検討すべき実験パラメータの数が増えて 
- N1.0 $\Delta$ S1.0 $\circ$ N1.5 $\Delta$ S1.5 a smooth

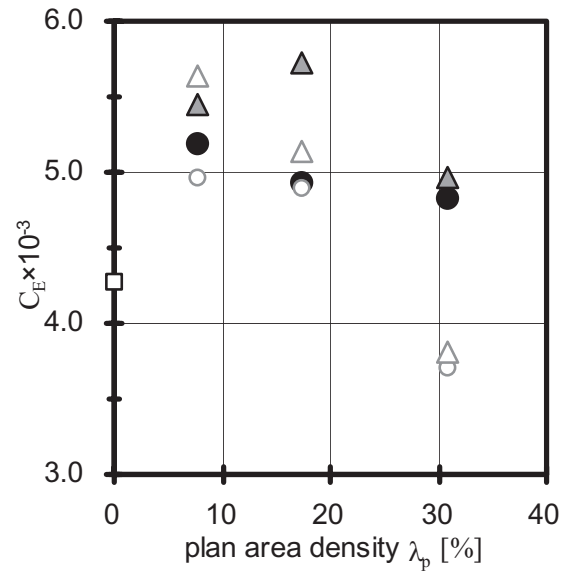

図 4 バルク係数 $C_{\mathrm{E}}$ と建蔽率 $\lambda_{\mathrm{p}}$ の関係

系統的な実験には膨大な時間を要する。

そこで本研究では、 $72 \mathrm{~cm}$ 四方 $(29 H$ 程度) の水槽を全ての模型配 列条件に対して用いスカラーソースサイズを統一した上で、まずは 各ケースのバルク係数の相対比較により模型配列の影響を議論する、 という方針をとる。

\section{3. 均一高さ粗度群の床面バルク係数 $C_{\mathrm{E}}$ の実験結果}

\section{1 建蔽率 $\lambda_{p}$ と $C_{\mathrm{E}}$ の関係}

均一高さの模型群による 4 条件、即ち、整形配列の N1.0、N1.5 および千鳥配列の S1.0、S 1.5 の床面バルク係数 $C_{\mathrm{E}}$ と建蔽率 $\lambda_{p}$ の関 係を図 4 に示す。なお、模型無し（滑面）の $C_{\mathrm{E}}$ を $\lambda_{p}=0 \%$ として併 せてプロットしている。

まず、 $\lambda_{p}=30.9 \%$ で模型高さ $1.5 \mathrm{H}$ の $\mathrm{N} 1.5$ と $\mathrm{S} 1.5$ 以外の寸べての 粗面の $C_{\mathrm{E}}$ は、滑面のそれに比べ大きな值を示している。粗面境界層 では、粗度群への form drag の増加に伴い模型近傍の風速は低下寸る が、模型周辺の 3 次元的気流場により上空乾燥空気と床面近傍湿潤 空気の混合が促進され、結果として大多数の条件で $C_{\mathrm{E}}$ が大きくなつ たのだと考えられる。また、配列および模型高さ毎にバルク係数に 対する建蔽率の影響を比較すると、S 1.0 のみ $\lambda_{p}=17.4 \%$ でピークを 示すのに対し、他の 3 ケースは概ね単調減少となっている。模型が 高密になると床面近傍流速が低減するのに加え、模型上面の乾燥空 気がキャノピー内に導かれにくくなることが要因と考えられる。

キャノピー内流れについては、 Okeによる 3 つの flow regimeがよ く知られている ${ }^{27)}$ 。即ち、低建蔽率ではキャニオン内で流れが地上 に再付着し、風上と風下側の両壁面付近にそれぞれ渦が出来る isolated flow、街路幅が狭くなると渦はキャニオンの幅に横長に広が り 1 つとなる wake interference flow、更に高い粗度密度条件では、キ ヤニオン内に安定した循環渦が生じる skimming flow が出現する、 というものである。立方体粗度群の整形配列について Oke は各流れ パターンの出現条件を粗度高さ $H$ と主流方向粗度間距離 $W$ の比で 対応づけており、それによると isolated flowは $H / W<0.4\left(\lambda_{p}<8.2 \%\right)$ 、 wake interference flow は $0.4<H / W<0.7\left(8.2 \%<\lambda_{p}<17.0 \%\right)$, skimming flow は $0.7<H / W\left(17.0 \%<\lambda_{p}\right)$ となっている。一方、孟ら ${ }^{28)}$ は千鳥 配列立方体粗度群の流れ場の乱流計測により、建蔽率 $10 \%$ 以下の場 合を isolated flow、建蔽率 30\%以上の場合を skimming flow、その他
- N1.0 $\Delta$ S1.0 $\circ$ N1.5 $\Delta$ S1.5 $\square$ smooth

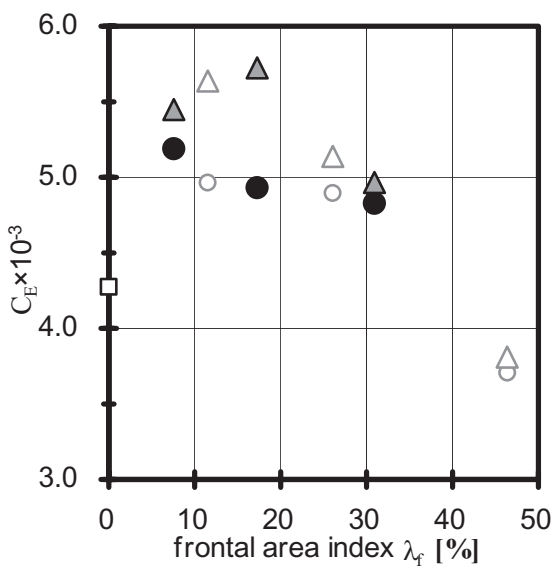

図 5 バルク係数 $C_{\mathrm{E}}$ と粗度率面積密度 $\lambda_{\mathrm{f}}$ の関係

を wake interference flow とそれぞれ定義している。 本実験では整形配列と千鳥配列、模型高さ $1 \mathrm{H}$ (立方体) と $1.5 \mathrm{H}$ (縦長の直方体) という違いがあるため、図 3 の横軸の $\lambda_{p}$ を一律に flow regime と対応づけることはできない。そのことが、4 ケースの プロットの傾向がまとまっていない一つの要因であろう。

\section{2 粗度立面積密度 $\lambda_{f}$ と $C_{\mathrm{E}}$ の関係}

模型高さの影響を考慮した粗度密度の指標として粗度立面積密度 $\lambda_{f}$ とバルク係数の関係を図 5 に示す。この図から模型高さの違いに よらず、整形配列と千鳥配列でそれぞれプロットがまとまった傾向 を示寸ことが分かる。以下、整形と千鳥のバルク係数の挙動を比較 しながら考察する。

まず全体として整形配列よりも千鳥配列のほうが大きな值を示し ている。また、低密の $\lambda_{f}<10 \%$ \%おび高密の $\lambda_{f}>30 \%$ でそれぞれ整形 と千鳥のバルク係数は極めて近い。 $\lambda_{f}$ が小さい条件では整形、千鳥 両配列ともに模型同士の間隔が十分に広く、模型周辺気流は単独模 型周辺のそれに近い振る舞いを見せるために配列間の違いが現れに くいのであろう。また $\lambda_{f}$ が大きな高密条件では整形、千鳥ともに流 れ場全体が skimming flow となるため、配列によるバルク係数の違 いが現れなくなると考えられる。

これに対し、 $10 \%<\lambda_{f}<27 \%$ では千鳥のバルク係数はピークを有 する一方で整形のそれはほぼ横ばいという異なった傾向を示してい る。萩島ら $\left.{ }^{22}\right)$ にると、この粗度密度条件では千鳥配列の床面抗力 係数は整形配列に比べ大きいことから、千鳥配列は整形配列に比心゙ 境界層内の速度欠損が大きく、 advection によるスカラ一輸送は小さ いと考えられる。にも関わらず、バルク係数が大きな值を示すのは 粗度群周辺の 3 次元的な流れ場の特徵に原因があると推測される。 孟ら ${ }^{28)}$ によると、千鳥配列の wake interference flow では上流側の模 型の lee eddy と斜め後方の frontal eddy が相互干涉することで、 isolated flow の場合に比べて lee eddyが小さくなり frontal eddyがかな り大きくなるという。この強い frontal eddy が床面近傍の湿潤空気と 上空の乾燥空気の交換を促進するため、 $\lambda_{\mathrm{f}}$ の増加に対して速度欠損 が大きいにも関わらずバルク係数がピークを示したのであろう。

一方で整形配列は同じ $\lambda_{f}$ 条件の千鳥配列に比べ主流方向の模型間 隔が狭いため、スカラー輸送が生じている床面付近まで乾燥空気が 
導入されにくく、結果として $C_{\mathrm{E}}$ のピークは観察されなかったのであ ろう。

\section{3 濾紙蒸発法による面内分布の測定結果}

濾紙蒸発法による測定結果を表 3 に示す。濾紙蒸発法の面積重み 平均した街区の平均バルク係数は、N1.0、S1.0 ともに塩分法による 水槽全体の平均值と良い一致を示している。

整形配列 N1.0 の $C_{\mathrm{E}}$ は gap、street、intersection の 3 部位で差は殆 どないが、その中では模型の風下側に位置する gap の $C_{\mathrm{E}}$ がやや小さ い。Oke ${ }^{27)}$ によれば $\lambda_{p}=17.4 \%$ の整形配列は wake interference flow と skimming flow のいずれかに相当すると考えられる。よって、gap には、ウェイク領域 (re-circulation region) と上空の乾燥空気が床面 付近に吹き込む ventilation region の両方が存在していた可能性が高 ( ${ }^{15)}$ 。結果として、gap $の C_{\mathrm{E}}$ が床面全体の $C_{\mathrm{E}}$ の平均值よりも小さ いことから、ventilation region の下降気流による蒸発促進よりも、ウ エイクの弱風領域による蒸発抑制の方が効果が上回っていたと考え られる。また、 street および intersection の $C_{\mathrm{E}}$ が塩分法による滑面の $C_{\mathrm{E}}$ (約 0.0043) よりも大きな值となっていることから、整形配列の 主流方向街路の流れは完全な滑面流とは異なり、粗度による乱れ生 成の影響を受け拡散が促進されたと推測される。

千鳥配列の S1.0 の部位別バルク係数は整形配列とは異なり差が 大きく、street が最大で intersection、gap の順となっている。

孟ら ${ }^{27)}$ によれば、濾紙蒸発法の実験条件である $\lambda_{p}=17.4 \%$ の千 鳥配列は wake interference flow に相当すると考えられる。Coceal ら ${ }^{29)}$ による $\lambda_{p}=25 \%$ の立方体粗度群千鳥配列の気流場についての DNS 解析による結果、即ち、高さ $0.25 H$ における流速は street が最大で intersection、gap の順となる、という事実と符合した結果と言えよう。

\section{4. 粗度群の高さのバラツキが床面バルク係数 $C_{\mathrm{E}}$ に及ぼす影響}

\section{1 不均一高さ粗度群の床面バルク係数 $C_{\mathrm{E}}$ の実験結果}

平均高さは $1.5 H$ で模型高さにバラツキのある配列のバルク係数 を図 6 に示す。なお、参照のため高さ $1.5 H$ の均一粗度群のデータも 併せて記載している。
表 $3 \lambda_{\mathrm{p}}=17.4 \%$ の立方体粗度群の床面バルク係数 $C_{\mathrm{E}}\left[\times 10^{-3}\right]$

\begin{tabular}{c|c|c|c|c|c}
\hline \multirow{2}{*}{ 測定法 } & \multirow{2}{*}{ 部位 } & \multicolumn{2}{|c|}{ 平均値 } & \multicolumn{2}{c}{ 標準偏差 } \\
\cline { 3 - 6 } & & $\mathrm{N} 1.0$ & $\mathrm{~S} 1.0$ & $\mathrm{~N} 1.0$ & $\mathrm{~S} 1.0$ \\
\hline \multirow{3}{*}{ 濾紙 } & Gap & 5.07 & 4.49 & 0.18 & 0.21 \\
\cline { 2 - 6 } 蒸発法 & Street & 5.20 & 6.52 & 0.12 & 0.22 \\
\cline { 2 - 6 } & Intersection & 5.14 & 6.05 & 0.11 & 0.03 \\
\cline { 2 - 6 } & 街区平均 & 5.14 & 5.73 & - & - \\
\hline 塩分法 & 街区全体 & 4.93 & 5.72 & 0.08 & 0.15 \\
\hline
\end{tabular}

模型高さ標準偏差の条件が $\sigma_{\mathrm{H}} / H_{\mathrm{av}}=0.58$ の N1.5-n、N1.5-s、S1.5-n、 S1.5-s の特性について比較する。この 4 ケースはいずれのプロット も低層模型配列が千鳥である配列（S1.5-n、S1.5-s）の方が、低層模 型配列が整形である配列（N1.5-n、N1.5-s）よりも $C_{\mathrm{E}}$ が大きくなっ ている。これは、高層模型に対して数が多く密度も高い低層模型の 配列が、床面のスカラー輸送に対して支配的であることを示唆して いると言えよう。

この傾向は同じ形状の粗度群の床面抗力 ${ }^{22}$ と対照的な結果であ る。文献 22)の抗力係数 $C_{\mathrm{D}}$ の実験結果によると、不均一高さ粗度群 は均一高さ粗度群に比べ大きな值を示している。また、低層模型が 同じ配列条件下では、高層模型配列が千鳥の $C_{\mathrm{D}}$ は整形のそれに比 べ大きい。一方、低層模型配列が千鳥と整形のケースを比較すると $C_{\mathrm{D}}$ には殆ど差は無い。即ち、境界層の速度欠損については、高層模 型の配列の影響が支配的である。

次に、高さ分布の有無が $C_{\mathrm{E}}$ に及ぼす影響について考察する。いず れの場合でも $\lambda_{p} \leqq 17.4 \%$ では不均一高さ粗度群の $C_{\mathrm{E}}$ が均一高さ (N1.5 および S1.5) のそれよりも小さいが、 $\lambda_{p}=30.9 \%$ では逆に不 均一高さ粗度群の $C_{\mathrm{E}}$ が均一高さ粗度群に比べ大きくなっている。特 に、 $1 H$ と $2 H$ 模型が同比率で混在する $\sigma_{\mathrm{H}} / H_{\mathrm{av}}=0.33$ の $\mathrm{N} 1.5-\mathrm{s} *$ は均一 高さ粗度群に比べ約 $18 \%$ 大きな值となっている。

低密条件では不均一高さ粗度の $C_{\mathrm{E}}$ が小さな值を示したのは、抗力 係数の増加、即ち、床面近傍流速の低減によるものであろう。一方、 高密条件で不均一高さ粗度群の $C_{\mathrm{E}}$ が大きくなったのは、高層模型の 前面に生じる強い下降気流により上空乾燥空気が床面近傍に供給さ れスカラー輸送が促進される効果が、床面近傍流速低減の影響を上

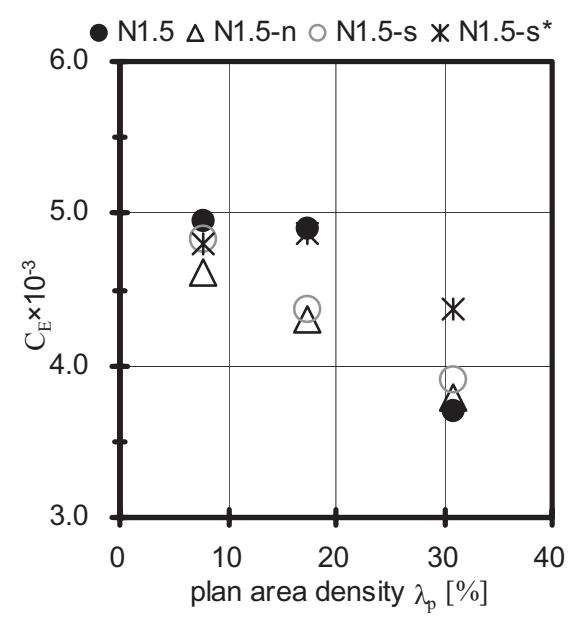

(a) 床面における模型配列が整形の場合

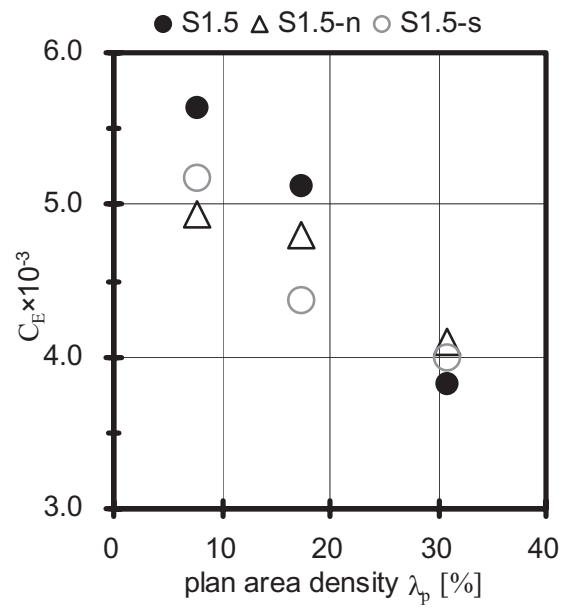

(b) 床面における模型配列が千鳥の場合

図 6 高さ $1.5 H$ の粗度群のバルク係数 $C_{\mathrm{E}}$ と建蔽率 $\lambda_{\mathrm{p}}$ の関係 
回った事が理由だと考えられる。また、抗力係数に対しては高層模 型配列の影響が、バルク係数に対しては低層模型配列の影響が支配 的となるのは、粗度の from drag の影響を強く受ける $C_{\mathrm{D}}$ と床面ごく 近傍における拡散現象を表す $C_{\mathrm{E}}$ が本質的に異なる物理現象により 決まることに起因するためであろう。

\section{2 既往研究との比較}

本節では、粗度群の高さの不均一性がスカラー輸送効率や気流場 に及ぼす影響について検討した既往の関連研究と本実験との比較を 行う。比較対象とするデータの一覧を表 4 に示す。測定手法、模型 配列条件、結果のまとめ方は異なっている点もあるが、これらを俯 瞰すると概ね本稿の結果と整合した一定の特性が推測される。

即ち、均一高さ粗度群の流れ場が isolated flow やwake interference flow となる低〜中 $\lambda_{p}$ 条件では、高さの不均一性は速度境界層を厚く、 床面近傍流速を小さくし、advectionによるスカラー輸送を減少させ る効果が大きい。そのため、均一高さ粗度群の $C_{\mathrm{E}}$ は不均一高さ粗度 群より大きくなる (例えば、 $\lambda_{p}=\lambda_{f}=25 \%$ の成田 $(2007)^{30)}$, Pascheke et al. $\left.(2008)^{21)}\right)$ 。

一方で、均一高さ粗度群の流れ場が skimming flow となるような 高 $\lambda_{\mathrm{p}}$ の条件では、粗度高さが不均一になると skimming flow とは異 なる流れ場が出現する。例えば、萩島ら $(2000)^{32)}$ には、高建蔽率の 不均一粗度群において高層模型の風上側に生じる強い下降気流や主 風向と平行な街路の床面近傍における蛇行流など 3 次元性の高い独 特の流れ場を報告している。また、萩島ら(2007) ${ }^{22)}$ は、不均一粗度 群は高 $\lambda_{p}$ 条件であっても form drag の支配的要因となる高層模型群 の相互の間隔は比較的広いため、wake interference や isolated flow と 類似した気流場になっている可能性を指摘している。こうした不均 一粗度群の 3 次元性の強い流れ場により、境界層全体としての主流 方向の速度欠損は大きいにも関わらず、床面のスカラー輸送に直接 関与する床面近傍の流速は比較的大きく、またキャニオン内に上空 の乾燥空気が供給されるため、スカラ輸送は大きくなる（例えば、 $\lambda_{p}=36 \%$ の成田ら $(1986 \text {, 塩分法 })^{20)} 、 \lambda_{p}=63 \%$ の義江ら $\left.(2007)^{31)}\right)$

\section{5. 結語}

本研究では、塩分法を用いた風洞模型実験により様々な形状の直 方体粗度群の床面のバルク係数の測定を行った。粗度形状は、平面 配置、建蔽率、粗度平均高さ、高さ分布の有無などにより合計 27 ケースのデータを取得している。以下に得られた知見を列記する。

- 均一高さ粗度の $C_{\mathrm{E}}$ は、模型高さの違い $(1 H 、 1.5 H)$ によら ず整形配列と千鳥配列のそれぞれが、粗度立面積密度 $\lambda_{f}$ によ って一定の関係で表現される。

- 低密 $\lambda_{\mathrm{f}}=7.7 \%$ \%よび高密 $\lambda_{\mathrm{f}}=30.4 \%$ の均一高さ粗度では、整形 配列の $C_{\mathrm{E}}$ は千鳥配列のそれと極めて近い。これに対し $\lambda_{f}=$ $17.4 \%$ では千鳥配列の $C_{\mathrm{E}}$ は明確なピークを示す一方で整形配 列の $C_{\mathrm{E}}$ はピークは見られず千鳥配列より小さな值となる。

- $\lambda_{\mathrm{p}} \leqq 17.4 \%$ では均一高さ粗度群の $C_{\mathrm{E}}$ が不均一高さ粗度群の それよりも大きいが、 $\lambda_{\mathrm{p}}=30.9 \%$ では逆に均一高さの方が不均 一高さ粗度群に比べ $C_{\mathrm{E}}$ は小さくなる。また、不均一高さ粗度 群では、低層模型の配列が $C_{\mathrm{E}}$ に及ぼす影響が大きい。これは、 床面抗力係数の挙動とは対照的な傾向である。
表 4 不均一高さ粗度群に関する既往研究との比較

\begin{tabular}{|c|c|c|c|}
\hline 文献 & 内容 & 模型配列 $($ () 1 & $\begin{array}{l}\text { 結果 } \\
\end{array}$ \\
\hline 本実験 & 塩分法 & $\lambda_{\mathrm{p}}=7.7 \sim 30.9 \%$ & $\begin{array}{l}C_{\mathrm{E}}\left(U_{20 \mathrm{H}} \text { 基準 }\right) \\
\lambda_{\mathrm{p}} \leqq 17.4 \% \quad: \text { 均一 }>\text { 不均一 } \\
\lambda_{\mathrm{p}}=30.9 \% \quad: \text { 均一<不均一 }\end{array}$ \\
\hline $\begin{array}{c}\text { 萩島ら } \\
\left.(2007)^{22)} 33\right)\end{array}$ & 床面抗力 & $\begin{array}{l}\text { 本実験と同じ } \\
\lambda_{\mathrm{p}}=4.4 \sim 39.4 \% \\
\end{array}$ & $C_{\mathrm{D}}\left(U_{20 \mathrm{H}}\right.$ 基準 $), \mathrm{Z}_{0}$ : 均一 $<$ 不均一 \\
\hline $\begin{array}{c}\text { Kanda } \\
(2006)^{34)}\end{array}$ & LES & $\begin{array}{c}\text { 整形, } \lambda_{\mathrm{p}}=11 \\
25,44 \% \\
\end{array}$ & $\begin{array}{r}C_{\mathrm{D}}\left(U_{\mathrm{Hmax}} \text { 基準 }\right): \text { 均一<不均一 } \\
\text { (特に } \lambda_{\mathrm{p}}=44 \% \text { で顕著) }\end{array}$ \\
\hline 成田 $\underset{30)}{(2007)}$ & 濾紙法 & $\begin{array}{c}\text { 整形 }(\mathrm{N} 1.0 \text { 他) } \\
\lambda_{\mathrm{p}}=25 \%\end{array}$ & $\begin{array}{l}\text { 風向によらず } \\
C_{\mathrm{E}}\left(U_{\delta} \text { 基準 }\right): \text { 不均一<均一 } \\
\text { 表面近傍風速 : 不均一<均一 }\end{array}$ \\
\hline $\begin{array}{l}\text { Pascheke et } \\
\text { al. }(2008)^{21)}\end{array}$ & $\begin{array}{l}\text { ナフタレン } \\
\text { 昇華法 }\end{array}$ & $\begin{array}{c}\text { 千鳥 }(\mathrm{S} 1.0 \text { 他) } \\
\lambda_{\mathrm{p}}=25 \%\end{array}$ & $\begin{array}{l}C_{\mathrm{E}}\left(U_{4.5 \mathrm{H}} \text { 基準 }\right): \text { 不均一<均一 } \\
C_{\mathrm{E}}\left(U_{1.0 \mathrm{H}} \text { 基準 }\right): \text { 不均一>均一 } \\
\text { 表面近傍風速 : 不均一<均一 }\end{array}$ \\
\hline $\begin{array}{c}\text { 成田ら } \\
(1986)^{20)}\end{array}$ & 塩分法 & $\begin{array}{c}\text { 整形 }(\mathrm{N} 1.0 \text { 他 }) \\
\lambda_{\mathrm{p}}=36 \% * 2 \\
\end{array}$ & $C_{\mathrm{E}}\left(U_{\delta}\right.$ 基準 $) \quad:$ 不均一>均一 \\
\hline $\begin{array}{l}\text { 義江ら } \\
(2007)^{31)}\end{array}$ & $\begin{array}{l}\text { 気温, 気 } \\
\text { 流分布 }\end{array}$ & $\begin{array}{l}\text { 整形 } * 3 \\
\lambda_{\mathrm{p}}=63 \%\end{array}$ & $\begin{array}{c}\text { 表面近傍風速 : 不均一>均一 } \\
\text { 表面近傍気温 : 不均一<均一 } \\
\text { (粗度表面加熱条件) }\end{array}$ \\
\hline $\begin{array}{l}\text { 萩島ら } \\
(2000)^{32)}\end{array}$ & 気流分布 & 整形 (N1.5-s*) & $\begin{array}{c}\text { 主風向と平行な街路の床面付 } \\
\text { 近気流が蛇行, 高層模型によ } \\
\text { る顕著な下降流と逆流域 }\end{array}$ \\
\hline
\end{tabular}

*1 主として対応する本実験の模型配列名， *2：風上側フェッチ無し，

*3 対応する配列なし

$U_{\mathrm{H} \max }:$ 粗度群高さの最高值における風速, $U_{\delta}$ : 境界層外風速

\section{謝辞}

本研究の一部は科学技術振興機構科学技術振興事業団・戦略的創 造研究推進事業の「都市生態圈-大気圈-水圈における水・エネルギ 一交換過程の解明」(代表 神田学)、文部省科学研究費 基盤研究(B) 都市気候モデルに適用する建築物が大気に与える空気力学つォーシ ング効果のモデル化（代表 谷本潤）、文部科学研究費 基盤研究(C) 塩分濃度法による不均一街区の平均交換係数の風洞実験 (代表 成 田建一)に拠る。ここに記して感謝の意を表する。

\section{参考文献}

1) 例えば、Ashie, Y., Ca, V.T. and Asaeda, T., Building canopy model for the analysis of urban climate, J. Wind Eng. Ind. Aerodyn., 81 ,pp.237-248、1999

2) 例えば、近藤裕昭, 劉発華，1 次元都市キャノピーモデルによる都市の 熱環境に関する研究、大気環境学会誌,33(3), pp.179-192、1998

3) 例えば、Grimmond, S. et al., International Urban Surface Energy Balance Model Comparison, http : //geography.kcl.ac.uk/micromet/ModelComparison/ Index.htm

4) 例えば、Ito, N., Kimura, K., Oka, J., A Field Experiment Study on the Convective Heat Transfer Coefficient on Exterior Surface of a Building, ASHRAE Trans, 78, 184-191. 1972

5)例えば、小林定教, 黒谷靖雄, 夏期の屋上面対流熱伝達率に関する研究, 日本建築学会計画系論文集,465, pp.11-17, 1994.11.

6) 例えば、 Hagishima. A.; Tanimoto. J., Field measurements for estimating the convective heat transfer coefficient at building surfaces, Building and Environment, vol 38(7) 、.pp 873 - 881,2003.6

7) Hagishima. A., Tanimoto. J., Narita. K., Intercomparisons of experimental research on convective heat transfer coefficient of urban surfaces, Boundary-Layer Meteorology 117(3), 551-576, 2005

8) Kanda, M., Kanega, M., Kawai, T., Sugawara, H., and Moriwaki, R., 
Roughness lengths for momentum and heat derived from outdoor urban scale models, Journal of Applied Meteorology and Climatology, 46, 1067-1079, 2007

w, J.F., Harman, I.N. and Belcher, S.E., Scalar Fluxes from urban street canyons Part 1: Laboratory simulation、 Boundary-Layer Meteorology, 113(3), pp.369 - 385, 2004

10) Narita, K-I, Experimental study of the transfer velocity for urban surfaces with a water evaporation method, Boundary-Layer Meteorology, vol. 122(2), pp. 293-320, 2007.2.

11) H. Kusaka, H. Kondo, Y. Kikegawa and F. Kimura, A Simple Single-Layer Urban Canopy Model For Atmospheric Models: Comparison With Multi-Layer And Slab Models, Boundary-Layer Meteorology, vol. 101(3), pp.329-358, 2004

12) V. Masson, A Physically-Based Scheme For The Urban Energy Budget In Atmospheric Models, Boundary-Layer meteorology, vol. 94(3), pp.357-397, 2000

13) V. T. Ca, Y. Ashie and Takashi Asaeda, A k-e Turbulence Closure Model For The Atmospheric Boundary Layer Including Urban Canopy, Boundary-Layer Meteorology, 102(3), pp.459-490, 2002

14) Kondo, H. , Genchi, Y., Kikegawa, Y., Ohashi, Y., Yoshikado, H., Komiyama, H., Development of a multi-layer urban canopy model for the analysis of energy consumption in a big city: Structure of the urban canopy model and its basic performance, Boundary-Layer Meteorology, Vol. 116(3), pp.395-421, 2005

15) Harman, I.N., Barlow, J.F., Belcher, S.E., Scalar Fluxes from urban street canyons Part 2: Model、Boundary-Layer Meteorology, 113(3), pp.387-410, 2004

16) Chyu, M.K., Goldstein, R.J., Local mass transfer in rectangular cavities with separated turbulent flow, 8th Int. Heat Transfer Conf. 3, 1065-1070, 1986

17) Aliaga, D.A., Lamb, J.P. and Klein, D.E., Convective heat transfer distributions over plates with square ribs from infrared thermography measurements, Int. J. Heat Mass Transfer, vol.37, pp.363-374., 1994

18）成田健一，関根毅，徳岡利一，地域蒸発量に及ぼすスケール効果に関 する風洞実験，日本建築学会中国支部研究報告集,No.13，pp.289-292., 1986

19) 成田健一, 関根毅, 徳岡利一, 市街地の蒸発量に及ぼす建物周辺気流 の影響に関する実験的研究, 日本建築学会計画系論文集,No.361, pp.10-20.1986

20) 成田健一, 関根毅, 徳岡利一, 市街地の蒸発量に及ぼす建物周辺気流 の影響に関する実験的研究 (続報), 日本建築学会計画系論文集, No.366, pp.1-10., 1986

21) Pascheke1, F., Barlow, J. F. and Robins, A., Wind-tunnel Modelling of Dispersion from a Scalar Area Source in Urban-Like Roughness, Boundary -Layer Meteorology, vol. 126(1), pp.1573-1472, 2008.1

22）萩島理、谷本潤、永山浩二、古賀正浩、高さの分布のある直方体粗度群 の抗力係数に関する風洞実験、日本建築学会環境系論文集、No.619, pp $39-45,2007.9$

23）例えば、成田健一，野々村喜民，小笠顕，自然風下における空面対流物 質伝達率の実測 都市域における建物外表面対流熱伝達率に関する実験 的研究(その 1), 日本建築学会計画系論文集, No.491, pp.49-56., 1997

24) Snyder, W. H., Castro, I. P., The critical Reynolds number for rough-wall boundary layers, J. Wind Engug Indust. Aerodyn., vol.90, pp.41-54, 2002
25) Offerle, B., Eliasson, I., Grimmond, C. S. B., Holmer, B., Surface heating in relation to air temperature, wind and turbulence in an urban street canyon, Boundary-Layer Meteorology, pp.1573-1472, Vol. 122(2), 2007.2.

26）萩島理，成田健一，菅原広史，谷本 潤，実大スケール都市キャノピー の表面対流熱伝達率分布に関する観測，日本建築学会環境系論文集 No.9626, pp.**_**, 2008.4.

27) Oke, T.R., Boundary Layer Climates 2nd edition, pp.266-268, London ; New York : Methuen、 1987

28）孟岩,老川進, 建物群内における流れと拡散に関する実験的研究 その 1 流れ場の測定, 大気環境学会誌 vol.32(2), pp.136-147, 1997

29) Coceal, O., Thomas, T. G., Belcher, S. E., Spatial variability of flow statistics within regular building arrays, Boundary-Layer Meteorol, vol. 125, pp.537-552, 2007

30) 成田健一，建物高さが不均一な街区の交換速度,日本建築学会大会学術 講演梗概集(D-2), pp.749-750, 2007

31）義江龍一郎，田中英之，白澤多一，小林剛，香港の高密集市街地におけ る風通しに関する研究 その 1 建蔽率と建物高さのバリエーション等 が歩行者レベルの風速・気温分布に及ぼす影響，日本建築学会大会学術 講演梗概集(D-2), pp.745-756, 2007

32）萩島理,片山忠久,谷本潤,森竹千景,江副紀子，高さの異なる直方体模型 群の周辺気流特性に関する風洞実験, 日本建築学会計画系論文集 No.538, pp.15-22, 2000.12

33）萩島理, 谷本潤, 永山浩二, 古賀正浩, 複雑形状都市におけるバルク運 動量輸送係数パラメタリゼーションのための風洞模型実験 第 2 報 境 界層厚さ, 粗度長, ゼロ面変位の推定, 日本建築学会学術講演梗概集 (D-2), pp.693-634, 2007

34) M. Kanda, Large-Eddy Simulations on the Effects of Surface Geometry of Building Arrays on Turbulent Organized Structures, Boundary-Layer Meteorology, Vol. 118(1), pp.151-168, 2006

（2008年 3 月24日原稿受理，2008年 6 月23日採用決定） 